\title{
Effects of Hedysarum coronarium L. (sulla) as a Green Manure along with Nitrogen Fertilizer on Maize Production
}

\author{
Mohammad Mahdi Akbarian'1, Tahereh Mojaradi' ${ }^{1 *}$ and Fatemeh Shirzadi² \\ ${ }^{1}$ Department of Agronomy, Faculty of Agriculture, Bam Branch, Islamic Azad University, Bam, Iran \\ ${ }^{2}$ College of Agriculture, Ferdowsi University of Mashhad, Iran \\ *Corresponding author: Tahereh Mojaradi, Email: mojaraditahereh@yahoo.com
}

Submission: August 12, 2020; Revision: September 8, 2020; Acceptance: December 20, 2020

\begin{abstract}
Green manure as a source of soil organic matter is an important indicator of potential agricultural ecosystems capable of preventing erosion, reducing runoff, increasing soil permeability, improving ventilation, ameliorating the temperature, and enhancing the function of microorganisms. Therefore, to investigate the effects of green manure Sulla (Hedysarum coronarium) and nitrogen fertilizer on maize yield in Kermanshah, an experiment was carried out as split-plot in a randomized complete block design with 3 replications. The main factor was the use of Sula in two levels, namely application and non-application, while, the sub-factor was the application of $\mathrm{N}$ fertilizer at four levels of zero, 200, 400 and $500 \mathrm{~kg} / \mathrm{ha}$. The highest leaf area index was observed by $400 \mathrm{~kg} / \mathrm{ha}$ $\mathrm{N}$ application along with green manure. Grains per ear determined using green manure and nitrogen fertilizer at levels of $0,200,400$ and $500 \mathrm{~kg} / \mathrm{ha}$ increased by $8,10,15$, and $15 \%$, respectively. The result showed that the Sulla green manure treatment increased the grain yield by $10 \%$ compared to the control treatment. Furthermore, the highest grain yield was obtained under two treatments of 400 and $500 \mathrm{~kg} \mathrm{~N} / \mathrm{ha}$ which was significantly different from other levels of $\mathrm{N}$ applications. The application of green manure application also increased the maize protein content by $8 \%$ with a rise in the highest levels of nitrogen fertilizer. Meanwhile, the application of Sulla as a green fertilizer or pre-planting had a positive impact on increasing soil organic matter and maize yield. Therefore, cultivation of Sulla can be considered a positive task towards sustainable agriculture.
\end{abstract}

Keywords: Pre-plant cultivation; protein content; sulla; urea

\section{INTRODUCTION}

One of the most important factors associated with the development of agriculture and human food security is soil fertility maintenance. According to Talgre et al. (2010) and Soleymani \& Shahrajabian (2017), the application of appropriate fertilizer is vital in increasing the quantity and quality of agricultural products. However, the need to intensify agricultural production has led to an increase in fertilizers and pesticide application, which has some adverse effects on the environment. Therefore, several studies have been carried out to determine methods that require less chemical use, such as green fertilizers. Green manure is a plant capable of producing biomass by creating live cover on the soil, preserving it from a variety of erosion before reaching the reproductive phase (Sainju et al., 2007; Selvi and Kalpana, 2009). The cover crop is a generic term that encompasses a wide range of plants cultivated for various ecological reasons asides economic purposes. Green manure is one of the most important soil organic matter sources and an index for agricultural ecosystems potential for preventing crop erosion and runoff, increasing permeability, ventilation, temperature, and enhancing microorganisms function (Steenwerth and Belina, 2008). Cover crops are 
cultivated for a variety of reasons, including inhibiting land cover expansion by weeds, controlling soil-borne diseases, enriching soil through nitrogen fixation, improving its structure and organic matter, preventing nitrogen leaching, and sustaining the cropping system (Kruidhof et al., 2008; Algan and Celen, 2011; Liebman et al., 2012).

Sulla, (Hedysarum coronarium), is a two-year plant from the leguminous family also known as Halian, Spanish sainfoin, Sweet Vetch, and Honeysuckle French. It is adapted to semi-arid Mediterranean environments and is one of the multipurpose plants for controlling soil erosion, environmental protection, landscape beauty, forage, and honey production (Jerković et al., 2010; Ruisi et al., 2011). According to Ruisi et al. (2011), this plant is cultivated in Portugal, Spain, Italy, Greece, Morocco, Algeria and Tunisia with flowering days from 139 to 154 days. Ruisi further stated that the Sulla plant comprises of the runner and semi-runner ecotypes. In addition, its growth season tends to occur from late September to late June of the following year. Meanwhile, the early stages experienced slow growth until March with an increase in late June, due to the rise in air temperature. Similar to many grassland plants, the seeds also fall, and the plant starts summer dormancy (Sulas et al., 2000). The sulla plant's root system is taproot with the branches on which the $\mathrm{N}$ fixing nodules are located. However, for nodule formation and nitrogen fixation, a particular breed of rhizobium called hedisari, which does not nodulate on any of the other species of the genus hedysarium is used (Córdoba et al., 2013). According to Sulas et al. (2000), for areas cultivated with Sulla for the first time, the seeds need to be inoculated with these bacteria. Furthermore, due to its nitrogen-fixing ability, the plant can be cultivated as low-density green manure before main crops such as maize require a great deal of nitrogen. In addition to nitrogen fixation by legumes, a study carried out by Damon et al. (2014) reported that residuals of the leguminous family plants improved phosphorus nutrition in subsequent cereals. Although green manure application is important in nutrient supply and capable of enhancing soil properties, however, these plants are not able to provide the whole nutrient required by crops. Therefore, applying green manures with less chemical fertilizers increases soil organic matter and enhances its properties and crop yield production.

Nitrogen is an essential nutrient applied as fertilizer in most cropping systems to increase the biomass, grain yield, and components (Montemurro and Giorgio, 2005). Nitrogen fertilizer, especially in its inorganic form, tends to positively or negatively affect soil microbial biomass. Furthermore, the application of inorganic fertilizers under nutrient scarcity can have a stimulating effect on microbial growth. This is because the application of nitrogen fertilizer produces a higher volume of biomass. Therefore higher straw and residues are returned to the soil with an increase in carbon substrate (Treseder, 2008). Meanwhile, high concentrations of chemical fertilizers adversely affect the soil's physical and biological properties (He et al., 2013), with lower nitrogen intake capable of reducing crop yields (Unkovich et al., 2010). Therefore, it is necessary to balance the amount of nitrogen fertilizer application and plant residues in the soil by properly managing crop residues associated with its application, thereby improving productivity with a short term (Pandiaraj et al., 2015).

Maize (Zea mays L.) is one of the four major cereals in the world and globally ranks third after wheat and rice. It is a staple food for a large human population in Latin America, Asia, Africa, and parts of Eastern Europe. According to Al-Kaisi \& Yin (2003) and Soleymani et al. (2012), this crop is cultivated in Iran and many other countries due to multiple applications. In addition to humans, maize is one of the most important livestock nutrition sources due to its high sugar content, starch, and forage yield (Gholamhoseini et al., 2013). There are very few studies on the cultivation effect of Sulla as green manure and its interaction with different levels of nitrogen on maize yield and its components. Therefore, this study aims to evaluate the yield and responsive traits of maize to Sulla green manure as well as the different levels of nitrogen fertilizer.

\section{MATERIALS AND METHODS}

In order to investigate the effectiveness of green manure (Hedysarum coronarium) and nitrogen fertilizer levels on maize yield and its components in Kermanshah, an experiment was carried out as split plot based using the randomized complete block design with 3 replications. The main factor, in two levels, was the application of Sulla and a non-application control system. The sub-factor was nitrogen fertilizer which was applied at four levels of zero, 200, 400, and 500 $\mathrm{kg} / \mathrm{ha}$. Furthermore, the amounts of nitrogen fertilizer obtained from the urea source were applied at three different times. Green manure cultivation was carried out in October 2015 and in March 2016. It was crushed and returned to the soil and mixed by rotator and disk before maize planting. One month after returning the green manure cover crop into the soil, the maize was planted in rows to achieve a density of 85,000 plants per hectare. The study site's soil properties were tested in two different times, before planting the Sulla green manure and before corn planting, as shown in Table 1 . 
Table 1. Soil properties before and after cultivation of Sulla as green manure

\begin{tabular}{|c|c|c|c|c|c|c|}
\hline $\mathrm{pH}$ & EC & $\mathrm{N} \%$ & $\mathrm{P}(\mathrm{ppm})$ & $\mathrm{K}(\mathrm{ppm})$ & OC \% & \\
\hline 7.9 & 4.1 & 0.1 & 12.8 & 391.4 & 1.02 & $\begin{array}{c}\text { Before } \\
\text { cultivation }\end{array}$ \\
\hline 8 & 2.1 & 0.16 & 34.3 & 589.1 & 1.59 & $\begin{array}{c}\text { After } \\
\text { cultivation }\end{array}$ \\
\hline
\end{tabular}

The studied traits include plant height, leaf area index, yield components, grain yield and biomass, as well as grain protein content. The leaf area was measured and recorded using a Delta $T$ model with the land area assigned to each plant $(75 \mathrm{~cm} \times 20 \mathrm{~cm})$, and the leaf area index was calculated using Equation 1.

$$
L A I=\frac{\text { Aall leaves }}{\text { Aplant }}
$$

Where, LAI denotes leaf area index without dimension, $A_{\text {all leaves }}$ is total area of leaves per plant $\left(\mathrm{cm}^{2}\right)$ and $A_{\text {plant }}$ is land area allocated to each plant $\left(\mathrm{cm}^{2}\right)$. In order to measure the percentage of protein in the seed, nitrogen value was first obtained by the Kjeldahl method and multiplied by conversion factor of $5.7 \%$ to estimate the grain protein content (Borghi et al., 1995).

To calculate the final grain yield of the plants in the third and fourth rows, the first half-meter from both sides of the rows were removed, therefore, a total area of approximately $4.5 \mathrm{~m}^{2}$ were harvested. The plants from each experimental plot were placed in separate sacks with six plants randomly selected from each sack to determine the number of grains per ear, which were further separated from the cob and stored at $70{ }^{\circ} \mathrm{C}$ in the oven for 72 hours. This produced to reach $0 \%$ grain moisture content with the grain yield calculated based on $14 \%$ moisture. One hundred seeds were counted and weighed using a seed counter, while the harvest index was calculated from the ratio of grain yield to total biomass.

Furthermore, analysis of variance was performed using the SAS 9.4 software, while the mean comparison was determined using Duncan's multiple range test.

\section{RESULTS AND DISCUSSION}

\section{Plant Height}

Analysis of variance indicated that the effects of green manure and nitrogen fertilizer on plant height were significant, as shown in Table 2. Means

Table 2. ANOVA analysis of some of Sulla properties in response to green manure and different levels of nitrogen

\begin{tabular}{|c|c|c|c|c|c|c|c|c|c|}
\hline S.O.V & $\mathrm{df}$ & $\begin{array}{l}\text { Plant } \\
\text { height }\end{array}$ & $\begin{array}{c}\text { Leaf } \\
\text { area } \\
\text { index }\end{array}$ & $\begin{array}{c}\text { 100-seeds } \\
\text { weight }\end{array}$ & $\begin{array}{l}\text { Number of } \\
\text { seed per } \\
\text { ear }\end{array}$ & Grain yield & $\begin{array}{l}\text { Biological } \\
\text { yield }\end{array}$ & $\begin{array}{l}\text { Harvest } \\
\text { index }\end{array}$ & $\begin{array}{l}\text { Seed } \\
\text { protein } \\
\text { content }\end{array}$ \\
\hline $\begin{array}{l}\text { Replication } \\
\text { (R) }\end{array}$ & 2 & 44.04 & 0.100 & 2.62 & 123.17 & 99827.8 & 5721554.5 & $23.02^{* *}$ & $1.89^{*}$ \\
\hline $\begin{array}{c}\text { Green } \\
\text { manure } \\
\text { (Sulla) (G) }\end{array}$ & 2 & $2281.50^{* *}$ & $2.542^{*}$ & $273.44^{* *}$ & $12973.5^{* *}$ & $5818887.8^{* *}$ & 237545.4 & $100.86^{* *}$ & $3.62^{* *}$ \\
\hline Error & 4 & 142.88 & 0.023 & 1.34 & 171.5 & 257195.3 & 4567232.7 & 4.84 & 0.25 \\
\hline $\begin{array}{l}\text { Nitrogen } \\
\text { fertilizer (N) }\end{array}$ & 1 & $474.94^{*}$ & $2.225^{* *}$ & $164.78^{* *}$ & $12648.44^{* *}$ & $38492731.6^{* *}$ & $168920503.1^{* *}$ & $23.29^{* *}$ & $2.37^{* *}$ \\
\hline $\mathrm{G} \times \mathrm{N}$ & 2 & 135.61 & $1.141^{*}$ & $7.54^{*}$ & $596.61^{*}$ & 2047.2 & $5331304.9^{*}$ & $8.95^{*}$ & 0.13 \\
\hline Error & 12 & 83.74 & 0.327 & 2.09 & 120.28 & 190251.6 & 1473000 & 2.31 & 0.30 \\
\hline CV (\%) & & 5.46 & 12.42 & 4.55 & 3.15 & 4.26 & 4.80 & 3.76 & 5.49 \\
\hline
\end{tabular}

${ }^{* *}$ and ${ }^{*}$ : significant in $1 \%$ and $5 \%$ level, respectively 
comparison showed that application of Sulla green manure increased plant height by $12 \%$ (Table 3 ). Furthermore, plant height also increased with a rise in $\mathrm{N}$ fertilizer application. The highest plant height was observed in $400 \mathrm{~kg} \mathrm{ha}^{-1}$ nitrogen treatment, which was not statistically different from $500 \mathrm{~kg} \mathrm{ha}^{-1}$ treatment, as shown in Table 3. Returning the green manure plants back into the soil not only increases the available phosphate and nitrogen rather it also enhances organic matter, and improves physical, chemical and biological properties of soil, thereby leading to higher nutrient uptake and crop growth. The increase in maize plant height in the presence of the residue of Sulla is due to the abundance of nutrients released from its residues.

Due to the important role of nitrogen in plants growth and development, it is quite sensible to determine its positive effect on plants height. According to Hussain et al. (2006), increased levels of nitrogen fertilizer showed the greatest effect on plant height. The increase in plant height is attributed to the rise in the number and length of internodes (Somasegaran and Hoben, 2012). Khan et al. (2011) reported that wheat crops showed higher heights due to the application of nitrogen which provided more nutrients to the plants and enhanced soil water.

\section{Leaf area index}

Analysis of variance showed that the effects of green manure and nitrogen fertilizer on leaf area index were significant (Table 2). Comparison of means and interaction effects of green manure and nitrogen fertilizer showed that leaf area index was higher in green manure treatment than control (no green manure application) as shown in Figure 1.

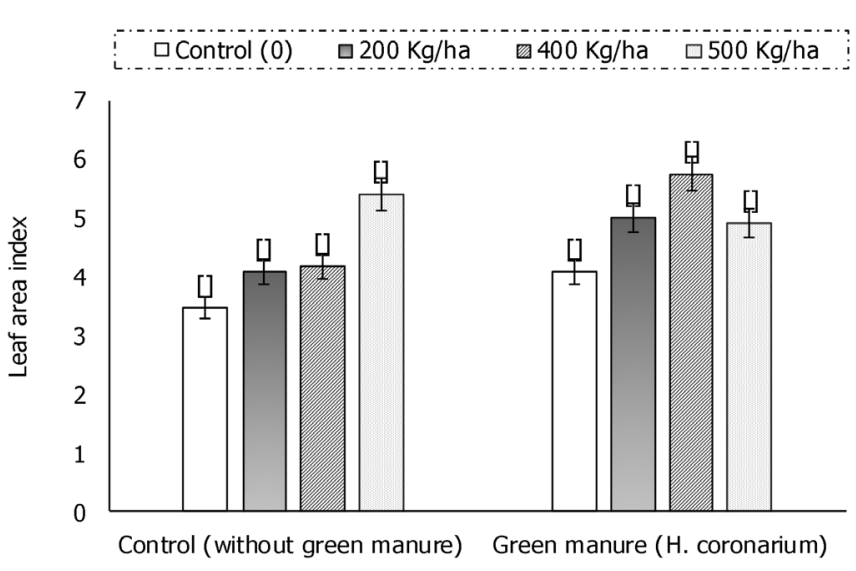

\section{Green manure leves}

Figure 1. Means comparison of interactive effects of Sulla green manure and nitrogen fertilizer on leaf area index

Overall, the leaf area index increased with a rise in nitrogen fertilizer application, however, no increment was observed when $500 \mathrm{~kg} \mathrm{ha}^{-1}$ of the fertilizer was applied along with Sulla green manure as shown in Figure 1. The highest leaf area index was observed in the application of $400 \mathrm{~kg} / \mathrm{ha}$ nitrogen fertilizer, while the use of green manure with $500 \mathrm{~kg} / \mathrm{ha}$ nitrogen fertilizer indicated no significant difference, as shown in Figure 1. Chutichudet Benjawan and Kaewsit (2007) reported the positive effect of green manure application on leaf area index. In addition, Eltelib et al. (2006) and Onasanya et al. (2009) also reported an increase in maize leaf area index due to nitrogen application. According to Ercoli et al. (2008), these increases are due to the direct effect of nitrogen on the expansion of the canopy cover,

Table 3. The simple effects of Sulla green manure and different levels of nitrogen on some maize properties

\begin{tabular}{|c|c|c|c|}
\hline Treatment & Plant height (cm) & Seed protein content (\%) & Grain yield (Kg/ha) \\
\hline \multicolumn{4}{|l|}{ Green manure levels } \\
\hline Control (without green manure) & $157.7^{b}$ & $9.64^{b}$ & $9754.7^{b}$ \\
\hline Green manure (H. coronarium) & $177.2^{\mathrm{a}}$ & $10.41^{\text {a }}$ & $10739.5^{a}$ \\
\hline \multicolumn{4}{|l|}{$\mathrm{N}$ fertilizer levels } \\
\hline Control (0) & $156.7^{c}$ & $9.32^{c}$ & $6663.7^{c}$ \\
\hline $200 \mathrm{Kg} / \mathrm{ha}$ & 163.7 bc & 9.76 bc & $10268.5^{b}$ \\
\hline $400 \mathrm{Kg} / \mathrm{ha}$ & $175.83^{a}$ & $10.25 \mathrm{ab}$ & $11853.8^{a}$ \\
\hline $500 \mathrm{Kg} / \mathrm{ha}$ & $173.5^{\text {a }}$ & $10.78^{\text {a }}$ & $12202.5^{\text {a }}$ \\
\hline
\end{tabular}

\footnotetext{
* Means with same letter(s) for each component are not significantly different based on Duncan test at $5 \%$ probability level.
} 
which consequently led to a rise in solar radiation's absorbance. The factors affecting leaf area and plant canopy development in maize are Soil fertility, genotype, plant density and climate. Patel et al. (2006) stated that the high leaf area index is due to nitrogen application, which positively affects leaf size and life span.

\section{Hundred Grain Weight}

Analysis of variance showed that the effects of green manure and nitrogen fertilizer on hundred-grain weight were significant (Table 2). Furthermore, by comparing the means and interaction of green manure with nitrogen, an average hundred grain weight of $24 \%$ higher in green manure than the control treatment (no green manure application) was obtained.

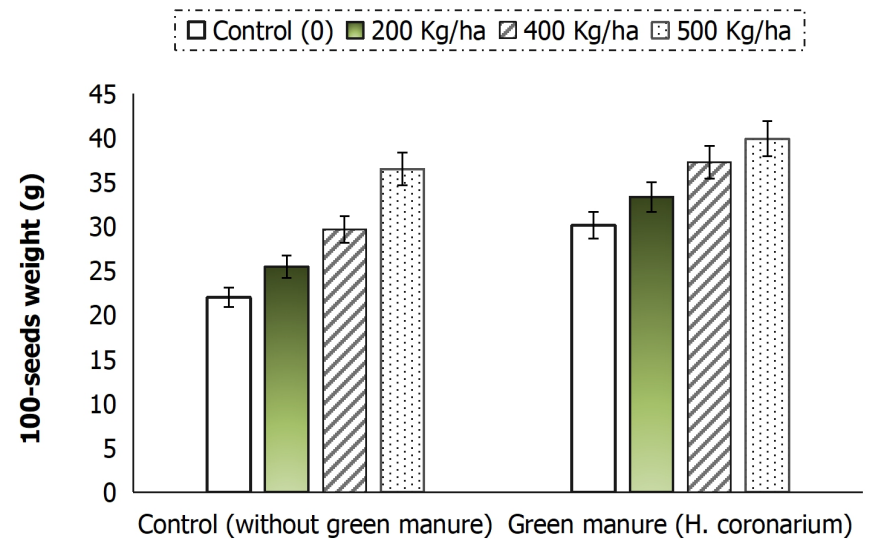

\section{Green manure leves}

Figure 2. Means comparison of the effect of Sulla green manure and nitrogen fertilizer on hundredgrain weight

Hundred-grain weights also increased with a rise in the application of nitrogen, however this was different between application and non-application of green manure. In green manure treatment, the application of 200,400 and $500 \mathrm{~kg} / \mathrm{ha}$ nitrogen fertilizer, increased hundred-grain weight by 16,35 and $66 \%$, respectively, compared to control (zero kg). Meanwhile, in the treatment of Sulla green manure application, the increase was 11,24 and $32 \%$, respectively, as shown in Figure 2. The highest hundred-grain weight was observed in joint application of Sulla green manure and $500 \mathrm{~kg} / \mathrm{ha}$ nitrogen fertilizer by enabling variation in essential plant nutrient sources and increasing maize uptake capacity, as shown inFigure 2. One thousand grain weight of maize which depends on the availability of photosynthetic materials during the filling period, replace or provide nutrients in the soil, promote fertility, increase organic matter, retain water, reduce evaporation, stimulate, increase and translocate photosynthetic materials to grains (Blanco-Canqui and Lal, 2009). Application of green manure application and chemical fertilizer leads to the gradual release of nutrients which in turn increases the grain weight and crop yield (Fageria, 2007). Bahrani (2015) stated that increasing nitrogen levels led to more redistribution of photosynthetic materials and higher grain weight.

\section{Number of Grains Per Ear}

Analysis of variance showed that the effects of Sulla green manure and nitrogen fertilizer, and their interaction on the number of kernels per ear were significant (Table 2). Interaction of green manure and nitrogen fertilizer on a number of grains per ear is shown in Figure 3.

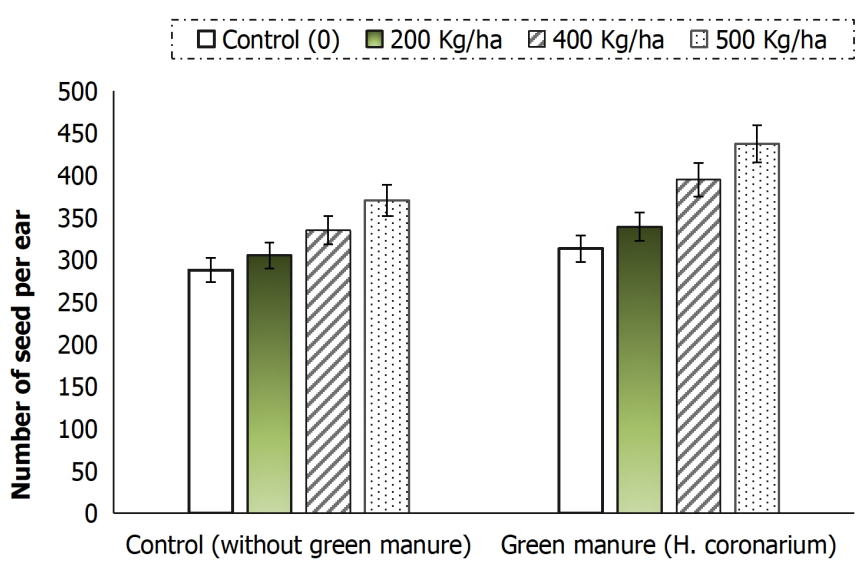

\section{Green manure leves}

Figure 3. Means comparison of the effect of Sulla green manure and nitrogen fertilizer on grain number per ear

The application of green manure increased the number of grains per ear however, this rise was not similar at different levels of nitrogen fertilizer. Furthermore, the application of green manure at nitrogen fertilizer levels of $0,200,400$ and $500 \mathrm{~kg} / \mathrm{ha}$, increased the number of grains per ear by $8,10,15$ and $15 \%$, respectively. Increase in the amount of nitrogen also led to a rise in the number of grains per ear compared to none nitrogen application. The highest increase (39\%) was observed in $500 \mathrm{~kg} /$ ha nitrogen fertilizer treatment with green manure with the number of grains per ear shown in Figure 3.

Furthermore, the increase in the number of grains per ear is due to green manure, which enhanced soil fertility and availability of nutrients. The number of grains per ear is one of the important components of grain yield affected by the plant's nutritional status. Therefore, the 
availability of nutrients, especially nitrogen improves the soil physical and chemical properties, thereby improving the crop pollination conditions. Therefore, improved pollination leads to a higher number of grains per ear. According to Rieger et al. (2008), the adequate availability of nutrients in soil improves plants growth and increases photosynthates' conversion to dry matter, thereby leading to higher fertile spikes in wheat.

\section{Grain Yield}

Analysis of variance showed that the effects of green manure and nitrogen fertilizer on grain yield were significant (Table 2). According to the means comparison results, the Sulla green manure increased yield up to $10 \%$ more than the control treatment, as shown in Table 3. Other studies also reported an increase in maize grain yield due to the application of green manure (Cherr et al., 2006; Tejada et al., 2008; Tao et al., 2017). The superiority of maize grain yield in Sulla green manure treatment over the control was because of the evaporation losses from the soil surface and moisture retention for a longer period. It was also due to the warm air and high evaporation from the soil during the maize growing season. Several studies have reported an increase in maize grain yield with a rise in soil moisture retention due to the residues (LimonOrtega et al., 2008). The impact of green fertilizers on maize is due to changes in soil microbial population and properties. Tao et al. (2017), stated that green manure's application changed the physicochemical properties of soil and its bacteria population in terms of order and sex. This is because plant root exudates have selective effects on soil microbial populations (Hartmann et al., 2009). The application of green manure, soil acidity, organic matter and change in trace elements (Table 1) in this experiment, is consistent with the results of other studies (Coolon et al., 2013; Tao et al., 2017). The use of legume plants such as Sulla with nitrogen fixation potential increases its availability in plants (Chen et al., 2014). Potassium also plays a role in increasing plant resistance to environmental stresses with the decomposition of soil organic matter dependent on factors such as temperature, soil moisture, acidity and fertility (García-Fraile et al., 2016). Therefore, in applying green manure, the availability of nitrogen is effective in improving maize yield. Belachew and Abera (2011) stated that the cultivation of legumes as green manure increased wheat grain yield with a rise in available nutrients and soil organic matter. Larsen et al. (2014) reported that maize yield significantly increased after cultivating green manure and returning them into the soil compared to the conventional tillage conditions.
They attributed to an increase in the destruction of the hard soil layer by plant roots and improved its conditioning and maize growth. The ratio of carbon to nitrogen in soil residues is one of the critical factors in determining green manure's effectiveness.

Application of green manure increased the phosphorus mobility in the soil and the availability of phosphorus which in turn led to a rise in the number of grains and ultimately increased the final yield. Surekha et al. (2006) stated that the simultaneous application of rice straw and legume increased soil nitrogen, its yield and components. These studies attributed legume plants' presence to rotation by increasing the activity of rhizobia and phosphate solubilizing bacteria and optimizing phosphorus uptake. Generally, the increase in maize grain yield due to the cultivation of green manure plants was dependent on several factors, including reducing soil evaporation and maintaining appropriate and accessible moisture because of residual cover, optimal use of water by crop, increasing the availability of nutrients, preventing weed growth, improving soil quality, maintaining nutrient balance, enhancing the growth of microorganisms, providing nutrients and preventing leaching.

Table 3 showed that an increase in nitrogen fertilizer application led to a rise in maize grain yield. The means comparison showed a significant difference between the nitrogen treatment and control. In terms of grain yield, nitrogen treatment levels of 400 and $500 \mathrm{~kg} \mathrm{~N} \mathrm{ha}^{-1}$ failed to show a significant difference, thereby producing the highest yield (Table 3 ). Addition of nitrogen fertilizer increased corn yield insignificantly to some extent, therefore its role cannot be ignored (Kogbe and Adediran, 2003). Several studies have shown that the application of nitrogen fertilizer up to $455 \mathrm{~kg} /$ ha under different tillage systems increased grain yield, while biomass and nitrogen uptake of maize led to a rise in the economic yield levels (Torbert et al., 2001). There are numerous reports on the positive effect of nitrogen fertilizer application on maize grain yield (Iqbal et al., 2009; Khan et al., 2011). For instance, the research carried out by Hokmalipour and Darbandi (2011) showed that nitrogen fertilizer had a positive effect on the yield and physiological properties of different maize cultivars. They further stated that the highest maize yield occurs at high levels of nitrogen. The results of other experiments also showed that the application of nitrogen fertilizer increased the vegetative and reproductive performance of maize crop compared to non-fertilizer treatment. Most of the studies attributed to this increase were mainly due to residues' effect on soil temperature and soil organic matter content (Vetsch and Randall, 2004). The use of 
nitrogen fertilizer is essential for the rapid growth of maize using maximum environmental resources and greater water/nutrient absorption used to enhance grain yield (Niehues et al., 2004). Increasing maize grain yield due to rise in nitrogen fertilizer application is justified by increasing soil nitrogen, leaf area as well as light absorption and utilization efficiency, thereby leading to a rise in crop growth rate and yield (Kogbe and Adediran, 2003). Zotarelli et al. (2009) stated that maize crop production was higher under treatments of green manure crops (flower vetch, rye) with lower nitrogen fertilizer application levels compared to no-green manure crops with high levels.

\section{Biological Yield}

Analysis of variance showed that the effects of nitrogen fertilizer as well as the interaction between green manure and nitrogen fertilizer on biological yield were significant (Table 2). Comparison of means showed that biological yield in response to different amounts of nitrogen fertilizer with or without green manure was different. Although nitrogen fertilizer application increased biological yield in comparison with the non-nitrogen fertilizer application, the rise was more significant without Sulla treatment, as shown in Figure 4.

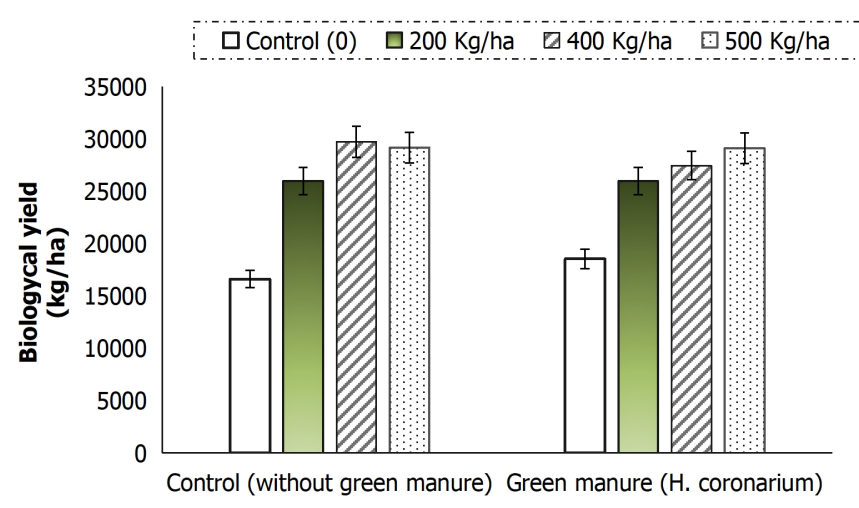

\section{Green manure leves}

Figure 4. Means comparison of the interactive effect of Sulla green manure and nitrogen fertilizer on biological yield

Applying green manure along with nitrogen fertilizer treatments of $0,200,400$, and $500 \mathrm{~kg} / \mathrm{ha}$ increased biological yield by $10 \%$, and reduced it by $1.5 \%, 10 \%$, and $6.5 \%$, respectively, as shown in Figure 4 . The highest biological yield was obtained by applying $400 \mathrm{~kg}$ $\mathrm{N}$ fertilizer without green manure. Furthermore, the rise in nitrogen utilization when using green manure did not have a significant positive effect on biological yield with most of the nitrogen leached out of the roots access. According to Chen et al. (2014), plants receive 70 to 80 percent of their required nitrogen during vegetative development, with only a small portion used at the seedling stage. Therefore, the gradual uptake of nitrogen during vegetative growth is important for biomass production. Nemeikšiene et al. (2011) stated that using legumes as green manure increased the biomass of wheat by improving the soil's organic nitrogen content. This is because the low carbon to nitrogen ratio and the legume family's green manure plants tend to decompose more rapidly and release nutrients to the next crop in the rotation sooner than green lignin-containing fertilizers with high carbon to nitrogen ratios ( $N^{\prime}$ Dayegamiye and Tran, 2011). According to several studies, inorganic fertilizers under nutrient scarcity have a stimulating effect on microbial growth. Therefore, the application of nitrogen fertilizer produces a higher volume of plants' biomass with the ability to provide more energy for the soil microbial population when their straw and residues returned back into the soil (Treseder, 2008; Spedding et al., 2004). However, high concentration of fertilizers reduces soil microbial biomass. Several studies reported that increase in soil nitrogen content leads to a rise in vegetative organs production, while leaf area index and ultimately increases the occurrence of photosynthesis and dry matter production (Dordas and Sioulas, 2008).

\section{Harvest Index}

Analysis of variance showed the significant effects of the interaction between green manure and nitrogen fertilizer on harvest index. Comparing the means between green manure and nitrogen fertilizer showed an increase in their harvest index by $0,4,10,16$ and $8 \%$, respectively (Figure 5 ). The highest harvest index was obtained from $400 \mathrm{~kg} \mathrm{~N} / \mathrm{ha}$ treatment along with Sulla green manure application, as shown in Figure 5.

Harvest index shows the distribution ratio of dry matter production between vegetative organs and grains yield, which changes and impact on the final grain yield. In integrated systems, chemical fertilizers reduce the temporary lack of nitrogen availability during the early growth season till the green manure materials decomposed and provided the required nutrients. This study showed that the combination of chemical and green manure improved grain filling and harvest index. The fertilizer integration releases the nitrogen and other essential nutrients needed by the crop to improve photosynthesis and crop production slowly. Furthermore, the maize crop under this condition supports more photosynthates to grains and produces higher harvest index. 


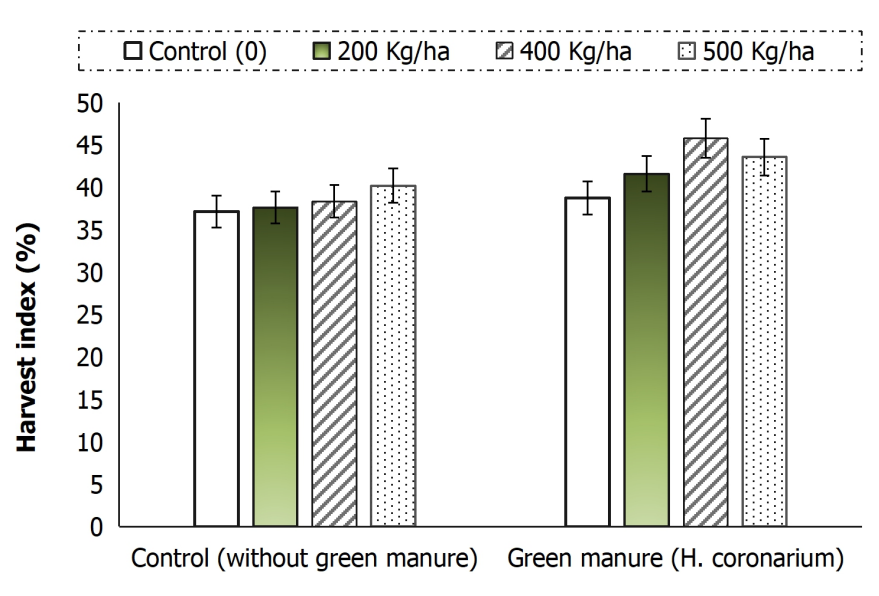

Green manure leves

Figure 5. Means comparison of the interactive effect of Sulla green manure and nitrogen fertilizer on harvest index

\section{Grain Protein Content}

Analysis of variance showed that the effects of green manure and nitrogen fertilizer on grain protein content were significant (Table 2). The mean comparison showed that the application of green manure increased corn protein content by $8 \%$ (Table 3 ). The average effect of the application of nitrogen fertilizer showed that with increasing application, the percentage of grain protein also increased. The treatment of $500 \mathrm{~kg} /$ ha $\mathrm{N}$ fertilizer led to the highest $(10 \%)$ grain protein, as shown in Table 3. Therefore, through a multiyear experiment, legumes' rotation was found as green manure with wheat crop and chemical fertilizer comprising of nitrogen uptake efficiency (Shah et al., 2011). Furthermore, an increase in nitrogen uptake leads to a rise in grain protein because it is a major protein structure element. Abdelhamid et al. (2004) stated that canola residues significantly increased pod protein of faba bean. Ghuman and Sur (2001) also reported an increase in maize grain yield and its quality in the tillage reduction system by maintaining plant residues in the soil. In addition, various studies also reported that nitrogen fertilizer application increased the amount of nitrogen imported from vegetable parts to seed was more than carbohydrates, thereby leading to a rise in the nitrogen concentration and protein percentage (Sharma et al., 2003). These results are similar to those of other studies which reported that an increase in the application of nitrogen fertilizer, leads to a rise in grain protein concentration increased (Guarda et al., 2004; Garrido-Lestache et al., 2005; Iqbal et al., 2005; Subedi et al., 2007). Furthermore, an increase in the percentage of maize grains protein with rising levels of nitrogen fertilizer was reported by other studies
(Lawrence et al., 2008; Ryan et al., 2008; Gheysari et al., 2009; Gholamhoseini et al., 2013).

\section{CONCLUSION}

In conclusion, the use of green manure as an organic fertilizer creates a more sustainable agricultural system. Furthermore, this research showed that the application of Sula green manure significantly increased the final yield, its components and protein content of maize grain. The Sulla plant has tap root system with branches on which the nodes are fixed, in addition to forage production, which has the potential for nitrogen fixation, decrease in weed population, increase in soil organic matter and erosion prevention. It also helps to improve the growth of the next plant in rotation. Therefore, the planting Sulla as green manure on maize crop is very beneficial. However, it is necessary to balance the vegetative residues of the green manure with the application of nitrogen fertilizer, in order to obtain maximum grain yield. Hence, choosing the right method of split, application time and type of nitrogen fertilizers, along with the right amount of green manure, eliminates the need for chemical fertilizer, while preventing environmental contamination and nitrate accumulation in plant organs. The results of this experiment showed that the application of $400 \mathrm{~kg} / \mathrm{ha}$ of nitrogen fertilizer with green Sulla manure was suitable for maize cultivation. This is because, in addition to improving the quality and quantity of maize yield, it also contributes to sustainable agricultural development by reducing the use of nitrogen fertilizer, thereby enhancing soil's physical and biological properties.

\section{ACKNOWLEDGMENTS}

The authors are grateful to the Faculty of Agriculture, Bam Branch, Islamic Azad University, Bam, Iran.

\section{CONFLICT OF INTEREST} interest.

The authors stated that there is no conflict of

\section{REFERENCES}

Abdelhamid, M. T., Horiuchi, T., \& Oba, S. (2004). Composting of rice straw with oilseed rape cake and poultry manure and its effects on faba bean (Vicia faba L.) growth and soil properties. Bioresource Technology, 93(2): 183-189. http://doi.org/10.1016/j.biortech.2003.10.012 
Algan, N., \& Celen, A. E. (2011). Evaluation of mung bean (Vigna radiata L.) as green manure in Aegean conditions in terms of soil nutrition under different sowing dates. African Journal of Agricultural Research, 6(7): 17441749. http://doi.org/10.5897/AJAR10.486

Al-Kaisi, M. M., \& Yin, X. (2003). Effects of nitrogen rate, irrigation rate, and plant population on corn yield and water use efficiency. Agronomy Journal, 95(6): 14751482. https://doi.org/10.2134/agronj2003.1475

Bahrani, A. (2015). Effect of irrigation methods and potassium fertilizer on grain yield and water use efficiency on corn. http://agris.fao.org/agris-search

Belachew, T., \& Abera, Y. (2011). Effect of green manuring in combination with nitrogen on soil fertility and yield of bread wheat (Triticum aestivum L.) under double cropping system of Sinana-dinsho, Southeast Ethiopia. Journal of Biodiversity and Environmental Sciences, 1(1): 1-11. http://doi.org/10.6084/M9.FIGSHARE.1353822.V1

Blanco-Canqui, H., \& Lal, R. (2009). Crop residue removal impacts on soil productivity and environmental quality. Critical Reviews in Plant Sciences, 28(3): 139-163. http:// doi.org/ 10.1080/07352680902776507

Borghi, B., Corbellini, M., Ciaffi, M., Lafiandra, D., Stefanis, E., Sgrulletta, D., Boggini, G., Fonzo, N., De Stefanis, E., \& Di, F. N. (1995). Effect of heat shock during grain filling on grain quality of bread and durum wheats. Australian Journal of Agricultural Research, 46(7): 1365-1380. http://doi.org/10.1016/S1161-0301(96)02040-0

Chen, C. P., Cheng, C. H., Huang, Y. H., Chen, C. T., Lai, C. M., Menyailo, O. V., Fan, L. J., \& Yang, Y. W. (2014a). Converting leguminous green manure into biochar: changes in chemical composition and $\mathrm{C}$ and $\mathrm{N}$ mineralization. Geoderma, 232: 581-588.

Chen, B., Liu, E., Tian, Q., Yan, C., \& Zhang, Y. (2014b). Soil nitrogen dynamics and crop residues. A review. Agronomy for Sustainable Development, 34(2): 429442. http://doi.org/ 10.1007/s13593-014-0207-8

Cherr, C. M., Scholberg, J. M. S., \& McSorley, R. (2006). Green manure approaches to crop production. Agronomy Journal, 98(2): 302-319. http://doi.org/10.2134/ agronj2005.0035

ChutichudetBenjawan, P. C., \& Kaewsit, S. (2007). Effects of green manures on growth, yield and quality of green okra (Abelmoschus esculentus L.) Har Lium Cultivar. Pakistan Journal of Biology Science, 10(7): 1028-1035. http://doi.org/10.3923/pjbs.2007.1028.1035

Coolon, J. D., Jones, K. L., Todd, T. C., Blair, J. M., \& Herman, M. A. (2013). Long-term nitrogen amendment alters the diversity and assemblage of soil bacterial communities in tallgrass prairie. PLoS One, 8(6). http://doi.org/10.1371/ journal.pone.0067884
Córdoba, E. M., Nadal, S., Román, B., \& Gónzalez-Verdejo, C. I. (2013). Collection, characterization and evaluation of wild (Hedysarum coronarium L.) populations from Andalusia (southern Spain). Australian Journal of Crop Science, 7(2): 165-172.

Damon, P. M., Bowden, B., Rose, T., \& Rengel, Z. (2014). Crop residue contributions to phosphorus pools in agricultural soils: A review. Soil Biology and Biochemistry, 74: 127137. http://doi.org/10.1016/j.soilbio.2014.03.003

Dordas, C. A., \& Sioulas, C. (2008). Safflower yield, chlorophyll content, photosynthesis, and water use efficiency response to nitrogen fertilization under rainfed conditions. Industrial Crops and Products, 27(1): 75-85. http://doi.org/10.1016/j.indcrop.2007.07.020

Eltelib, H. A., Hamad, M. A., \& Ali, E. E. (2006). The effect of nitrogen and phosphorus fertilization on growth, yield and quality of forage maize (Zea mays L.). Journal of Agronomy, 5(3): 515-518. http://doi.org/10.3923/ ja.2006.515.518

Ercoli, L., Lulli, L., Mariotti, M., Masoni, A., \& Arduini, I. (2008). Post-anthesis dry matter and nitrogen dynamics in durum wheat as affected by nitrogen supply and soil water availability. European Journal of Agronomy, 28(2): 138-147. http://doi.org/10.1016/j.eja.2007.06.002

Fageria, N. K. (2007). Green manuring in crop production. Journal of Plant Nutrition, 30(5): 691-719. http://doi. org/10.1080/01904160701289529

García-Fraile, P., Benada, O., Cajthaml, T., Baldrian, P., \& Lladó, S. (2016). Terracidiphilus gabretensis gen. nov., sp. nov., an abundant and active forest soil acidobacterium important in organic matter transformation. Applied and Environmental Microbiology, 82(2): 560-569. http://doi. org/10.1128/AEM.03353-15

Garrido-Lestache, E., López-Bellido, R. J., \& López-Bellido, L. (2005). Durum wheat quality under Mediterranean conditions as affected by $\mathrm{N}$ rate, timing and splitting, $\mathrm{N}$ form and $\mathrm{S}$ fertilization. European Journal of Agronomy, 23(3): 265-278. http://doi.org/10.1016/j. eja.2004.12.001

Gheysari, M., Mirlatifi, S. M., Homaee, M., Asadi, M. E., \& Hoogenboom, G. (2009). Nitrate leaching in a silage maize field under different irrigation and nitrogen fertilizer rates. Agricultural Water Management, 96(6): 946-954.

Gholamhoseini, M., AghaAlikhani, M., Mirlatifi, S. M., \& Sanavy, S. A. M. M. (2013). Weeds-Friend or foe? Increasing forage yield and decreasing nitrate leaching on a corn forage farm infested by redroot pigweed. Agriculture, Ecosystems \& Environment, 179: 151-162.

Ghuman, B. S., \& Sur, H. S. (2001). Tillage and residue management effects on soil properties and yields of 
rainfed maize and wheat in a subhumid subtropical climate. Soil \& Tillage Research, 58(1-2): 1-10. http:// doi.org/10.1016/S0167-1987(00)00147-1

Guarda, G., Padovan, S., \& Delogu, G. (2004). Grain yield, nitrogen-use efficiency and baking quality of old and modern Italian bread-wheat cultivars grown at different nitrogen levels. European Journal of Agronomy, 21(2): 181-192. http://doi.org/10.1016/j.eja.2003.08.001

Hartmann, A., Schmid, M., Van Tuinen, D., \& Berg, G. (2009). Plant-driven selection of microbes. Plant Soils, 321(1-2): 235-257. http://doi.org/10.1007/s11104-008-9814-y

He, Y., Dong, Y., Xiao, S., Peng, Q., Liu, X., \& Sun, L. (2013). Effects of nitrogen fertilization on soil microbial biomass and community functional diversity in temperate grassland in inner Mongolia, China. Clean-Soil, Air and Water, 41: 1216-1221. http://doi.org/10.1002/ clen.201200021

Hokmalipour, S., \& Darbandi, M. H. (2011). Physiological growth indices in corn (Zea mays L.) cultivars as affected by nitrogen fertilizer levels. World Applied Sciences Journal, 15(12): 1800-1805.

Hussain, I., Khan, M. A., \& Khan, E. A. (2006). Bread wheat varieties as influenced by different nitrogen levels. Journal of Zhejiang University-SCIENCE B, 7(1): 70-78. http://doi.org/10.1631/jzus.2006.B0070

Iqbal, M. M., Akhter, J., Mohammad, W., Shah, S. M., Nawaz, H., \& Mahmood, K. (2005). Effect of tillage and fertilizer levels on wheat yield, nitrogen uptake and their correlation with carbon isotope discrimination under rainfed conditions in north-west Pakistan. Soil \& Tillage Research, 80(1-2): 47-57.

Iqbal, S. M. (2009). Effect of crop residue qualities on decomposition rates, soil phosphorus dynamics and plant phosphorus uptake (Doctoral dissertation).

Jerković, I., Tuberso, C. I., Gugić, M., \& Bubalo, D. (2010). Composition of sulla (Hedysarum coronarium L.) honey solvent extractives determined by GC/MS: norisoprenoids and other volatile organic compounds. Molecules, 15(9): 6375-6385. http://doi.org/10.3390/molecules15096375

Khan, H. Z., Iqbal, S., Iqbal, A., Akbar, N., \& Jones, D. L. (2011). Response of maize (Zea mays L.) varieties to different levels of nitrogen. Crop Environments, 2(2): 15-19. http://doi.org/10.19045/bspab.2016.50075

Kogbe, J. O. S., \& Adediran, J. A. (2003). Influence of nitrogen, phosphorus and potassium application on the yield of maize in the savanna zone of Nigeria. African Journal of Biotechnology, 2(10): 345-349. http://doi.org/10.5897/ AJB2003.000-1071

Kruidhof, H. M., Bastiaans, L., \& Kropff, M. J. (2008). Ecological weed management by cover cropping: effects on weed growth in autumn and weed establishment in spring. Weed Research, 48(6): 492-502. http://doi. org/10.1111/j.1365-3180.2008.00665.x

Larsen, E., Grossman, J., Edgell, J., Hoyt, G., Osmond, D., \& $\mathrm{Hu}$, S. (2014). Soil biological properties, soil losses and corn yield in long-term organic and conventional farming systems. Soil \& Tillage Research, 139: 37-45. http://doi. org/10.1016/j.still.2014.02.002

Lawrence, J. R., Ketterings, Q. M., \& Cherney, J. H. (2008). Effect of nitrogen application on yield and quality of silage corn after forage legume-grass. Agronomy Journal, 100(1): 73-79. http://doi.org/10.2134/agronj2007.0071

Lebman, M., Graef, R. L., Nettleton, D., \& Cambardella, C. A. (2012). Use of legume green manures as nitrogen sources for corn production. Renewable Agriculture and Food Systems, 27(3): 180-191. http://doi.org/10.1017/ S1742170511000299

Limon-Ortega, A., Govaerts, B., \& Sayre, K. D. (2008). Straw management, crop rotation, and nitrogen source effect on wheat grain yield and nitrogen use efficiency. European Journal of Agronomy, 29(1): 21-28. http:// doi.org/10.1016/j.eja.2008.01.008

Montemurro, F., \& De Giorgio, D. (2005). Quality and nitrogen use efficiency of sunflower grown at different nitrogen levels under Mediterranean conditions. Journal of Plant Nutrition, 28(2): 335-350. http://doi.org/10.1081/PLN200047627

N'Dayegamiye, A., \& Tran, T. S. (2001). Effects of green manures on soil organic matter and wheat yields and $\mathrm{N}$ nutrition. Canadian Journal of Soil Science, 81(4): 371382. http://doi.org/10.4141/S00-034

Nemeikšienè, D., Arlauskienè, A., \& Šlepetienè, A. (2011). Improving winter wheat yields in organic farming systems through innovations in green manure management. In Environment. Technology. Resources-Proc. 8th International Scientific-Practical Conference, 11: 268275. http://doi.org/10.17770/etr2011vol2.992

Niehues, B. J., Lamond, R. E., Godsey, C. B., \& Olsen, C. J. (2004). Starter nitrogen fertilizer management for continuous no-till corn production. Agronomy Journal, 96(5): 1412-1418. http://doi.org/10.2134/ agronj2004.1412

Onasanya, R. O., Aiyelari, O. P., Onasanya, A., Oikeh, S., Nwilene, F. E., \& Oyelakin, O. O. (2009). Growth and yield response of maize (Zea mays L.) to different rates of nitrogen and phosphorus fertilizers in southern Nigeria. World Journal of Agricultural Science, 5(4): 400-407.

Pandiaraj, S., Selvaraj, S., \& Ramu, N. (2015). Effects of crop residue management and nitrogen fertilizer on soil nitrogen and carbon content and productivity of wheat 
(Triticum aestivum L.) in two cropping systems. Journal of Agricultural Science and Technology, 17(1): 249-260.

Patel, J. B., Patel, V. J., \& Patel, J. R. (2006). Influence of different methods of irrigation and nitrogen levels on crop growth rate and yield of maize (Zea mays L.). Indian Journal of Crop Science, 1(1-2): 175-177.

Rieger, S., Richner, W., Streit, B., Frossard, E., \& Liedgens, M. (2008). Growth, yield, and yield components of winter wheat and the effects of tillage intensity, preceding crops, and $\mathrm{N}$ fertilization. European Journal of Agronomy, 28(3): 405-411. http://doi.org/10.1016/j. eja.2007.11.006

Ruisi, P., Siragusa, M., Di Giorgio, G., Graziano, D., Amato, G., Carimi, F., \& Giambalvo, D. (2011). Phenomorphological, agronomic and genetic diversity among natural populations of sulla (Hedysarum coronarium L.) collected in Sicily, Italy. Genetic Resources and Crop Evolution, 58(2): 245-257. http://doi.org/10.1007/ s10722-010-9565-5

Ryan, J., Pala, M., Masri, S., Singh, M., \& Harris, H. (2008). Rainfed wheat-based rotations under Mediterranean conditions: Crop sequences, nitrogen fertilization, and stubble grazing in relation to grain and straw quality. European Journal of Agronomy, 28(2): 112-118. http:// doi.org/10.1016/j.eja.2007.05.008

Sainju, U. M., Schomberg, H. H., Singh, B. P., Whitehead, W. F., Tillman, P. G., \& Lachnicht-Weyers, S. L. (2007). Cover crop effect on soil carbon fractions under conservation tillage cotton. Soil \& Tillage Research, 96(1-2): 205-218. http://doi.org/10.1016/j.still.2007.06.006

Selvi, R. V., \& Kalpana, R. (2009). Potentials of green manure in integrated nutrient management for rice-a review. Agricultural Reviews, 30(1): 40-47.

Shah, Z., Ahmad, S. R., Rahman, H. U., Latif, A., \& Shah, A. (2011). Rice and wheat yields in relation to biomass of green manure legumes. Sarhad Journal of Agriculture, 27(1): 73-84.

Sharma, S., Upadhyay, R. G., \& Sharma, C. R. (2003). Response of various levels of nitrogen and phosphorus application on growth, physiological parameters and yield of (Vigna radiate L.) Wilczek under rainfed and mid-hill conditions of Himachal Pradesh. Indian Journal of Agricultural Research, 37(1): 52-55.

Soleymani, A., \& Shahrajabian, M. H. (2017). Assessment of ET-HS model for estimating crop water demand and its effects on yield and yield components of barley and wheat in semi-arid region of Iran. Cercetari Agronomy Moldova, 50(4): 37-49. http://doi.org/10.1515/ cerce-2017-0034

Soleymani, A., Khoshkharam, M., \& Shahrajabian, M. H. (2012). Germination rate and initial growth of silage corn grown under various fertility systems. Research on Crops, 13(3): 1035-1038.

Somasegaran, P., \& Hoben, H. J. (2012). Handbook for Rhizobia: Methods in Legume-Rhizobium Technology. Springer Science \& Business Media.

Spedding, T. A., Hamel, C., Mehuys, G. R., \& Madramootoo, C. A. (2004). Soil microbial dynamics in maize-growing soil under different tillage and residue management systems. Soil Biology and Biochemistry, 36(3): 499-512. http://doi.org/10.1016/j.soilbio.2003.10.026

Steenwerth, K., \& Belina, K. M. (2008). Cover crops enhance soil organic matter, carbon dynamics and microbiological function in a vineyard agroecosystem. Applied Soil Ecology, 40(2): 359-369. http://doi.org/10.1016/j. apsoil.2008.06.006

Subedi, K. D., Ma, B. L., \& Xue, A. G. (2007). Planting date and nitrogen effects on grain yield and protein content of spring wheat. Crop Science, 47(1): 36-44. http://doi. org/10.2135/cropsci2006.02.0099

Sulas, L., Stangoni, A. P., Re, G. A., \& Ledda, L. (2000). Growing cycle of (Hedysarum coronarium L.) (sulla): relationship between plant density, stem length, forage yield and phytomass partitioning. In: (Sulas L.) (ed.). Legumes for Mediterranean forage crops, pastures and alternative uses. Zaragoza: CIHEAM, 2000. p. 147-151 (Cahiers Options Méditerranéennes; n. 45).

Surekha, K., Pavan Chandra Reddy, K., Padma Kumari, A. P., \& Sta Cruz, P. C. (2006). Effect of straw on yield components of rice (Oryza sativa L.) under rice-rice cropping system. Journal of Agronomy and Crop Science, 192(2): 92-101. http://doi.org/10.1111/j.1439037X.2006.00192.X

Talgre, L., Lauringson, E., \& Makke, A. (2010). Amounts of nitrogen and carbon returned to soil depending on green manure and the effect on winter wheat yield. Agronomy Research, 8(2): 487-492.

Tao, J., Liu, X., Liang, Y., Niu, J., Xiao, Y., Gu, Y., Ma, L., Meng, D., Zhang, Y., Huang, W., \& Peng, D. (2017). Maize growth responses to soil microbes and soil properties after fertilization with different green manures. Applied Microbiology and Biotechnology, 101(3): 1289-1299. http://doi.org/10.1007/s00253-016-7938-1

Tejada, M., Gonzalez, J. L., García-Martínez, A. M., \& Parrado, J. (2008). Effects of different green manures on soil biological properties and maize yield. Bioresource Technology, 99(6): 1758-1767. http://doi.org/10.1016/j. biortech.2007.03.052

Torbert, H. A., Potter, K. N., \& Morrison, J. E. (2001). Tillage system, fertilizer nitrogen rate, and timing effect on corn yields in the Texas Blackland Prairie. Agronomy 
Journal, 93(5): 1119-1124. http://doi.org/10.2134/ agronj2001.9351119x

Treseder, K. K. (2008). Nitrogen additions and microbial biomass: A meta-analysis of ecosystem studies. Ecology Letter, 11(10): 1111-1120. http://doi.org/10.1111/ j.1461-0248.2008.01230.x

Unkovich, M., Baldock, J., \& Forbes, M. (2010). Variability in harvest index of grain crops and potential significance for carbon accounting: examples from Australian agriculture. In Advances in agronomy, 105, pp. 173-219. Academic Press.

Vetsch, J. A., \& Randall, G. W. (2004). Corn production as affected by nitrogen application timing and tillage. Agronomy Journal, 96(2): 502-509.

Zotarelli, L., Avila, L., Scholberg, J. M. S., \& Alves, B. J. R. (2009). Benefits of vetch and rye cover crops to sweet corn under no-tillage. Agronomy Journal, 101(2): 252260. http://doi.org/10.2134/agronj2008.0033x 